\title{
The High Prevalence of Diabetes Mellitus on a Central Pacific Island
}

\author{
P. Zimmet, P. Taft, A. Guinea, W. Guthrie, and K. Thoma \\ Dept. of Metabolic Medicine and Epidemiology, Southern Memorial Hospital, and Ewen Downie Metabolic Unit, Alfred Hospital, \\ Melbourne, Australia
}

\begin{abstract}
Summary. A diabetes prevalence study on an isolated urbanized Central Pacific island has established a prevalence rate of $34.4 \%$ in individuals aged 15 years and over. Of these, $10.4 \%$ had previously known diabetes; in the others the diagnosis was made on the basis of a plasma glucose level of at least $160 \mathrm{mg} / 100 \mathrm{ml} 2 \mathrm{~h}$ after a $75 \mathrm{gm}$ oral glucose load. A further $11.3 \%$ of the subjects had borderline diabetes as judged by a $2-\mathrm{h}$ plasma glucose of between 140 and $159 \mathrm{mg} / 100 \mathrm{ml}$. Of the diabetics, $72 \%$ had a positive family history of diabetes. The high prevalence rate appears to be related to a number of factors including a diabetic genotype, urbanization, and obesity.
\end{abstract}

Key words: Diabetes, borderline diabetics, Micronesia, Pacific, prevalence, urbanization, obesity.

The first major epidemiological study of diabetes prevalence in a population was made in Oxford, Massachusetts, U.S. A. by Wilkerson and Krall [1]. They found the prevalence of diabetes in their group to be $1.7 \%$.

It is against this Caucasian diabetes prevalence rate that the more recent studies on native populations assume a great deal of importance. Diabetes is reported to be rare amongst Eskimos [2, 3, 4], but Bennett and co-workers [5] have reported a prevalence of $30.6 \%$ among American Pima Indians aged 15 years and over - the highest yet recorded. High diabetes prevalence rates have also been reported in other North American Indian tribes, in Polynesians and in Micronesians and these various studies have been recently summarized by West [6].

This paper reports the results of a diabetes survey on a Pacific island where a considerable degree of urbanization has taken place over the last decade.

\section{Material and Methods}

\section{a. Geographical and Historical Background}

Nauru is situated in the Central Pacific at longitude $160^{\circ} 55^{\prime}$ east and latitude $0^{\circ} 32^{\prime}, 37$ miles south of the equator. Its area is about 6263 acres, the island being 12 miles in circumference. It is one of the most isolated islands in the Pacific, being 2500 miles from Sydney, 1600 miles from Honolulu, and 3000 miles from Tokyo.

The present population consists of approximately 3900 Nauruans, 1800 Gilbert and Ellice Islanders, 900 Chinese, and 700 others, mainly Australians and New Zealanders. The Nauruans have one of the highest per capita incomes in the world (US\$ 30,000 per annum). The phosphate industry (controlled by the Republic of Nauru since 1970) is the reason for the country's wealth. Four-fifths of the total area of the island - in fact, all but a narrow coastal plain - contains high-grade phosphate ore.

The island lies at the intersection of the three Pacific ethnic areas of Melanesia, Micronesia, and Polynesia. In appearance, the Nauruan phenotype corresponds most closely to that of the Micronesians.

\section{b. Methods}

Subjects studied. The survey was carried out over a 4-day period in May, 1975. The population selected for study included all Nauruan individuals, 15 years and older, residing in two of the twelve districts of the island. This provided a sample of $16 \%$ of the island population above 15 years of age. Of the 304 people on the roll, $221(73 \%)$ presented for testing and this provided a sample representing $11.5 \%$ of the island population in the required age group. The validity of 
this as a representative sample was demonstrated by the fact that the age and sex distribution corresponded to that of the overall island population as shown in a 1972 actuarial survey.

Of the 221 people studied, there were 107 $(48.4 \%)$ males and $114(51.6 \%)$ females. The age and sex distributions of the two district samples were similar.

We were able to obtain some data relating to 48 (i. e. $58 \%$ ) of the 83 non-attenders. Their age and sex distribution corresponded to that of those who attended and among them were 5 known diabetics.

Procedure. The subjects were not prepared for the test with a formal high carbohydrate diet and all had been on unrestricted diets; the average Nauruan daily diet contains over $350 \mathrm{~g}$ of carbohydrate.

All subjects were asked to fast and to attend the Clinic between $8.00 \mathrm{a}$. m. and $10.00 \mathrm{a} . \mathrm{m}$. On arrival at the survey centre, a fasting blood sample was taken and a $75 \mathrm{~g}$ oral glucose load was administered. Following this, the subjects were seen by one of the doctors (accompanied by a local nurse who acted as interpreter where necessary). A record of family history of diabetes, alcohol and cigarette consumption, current drug therapy, known diseases, and obstetric history (parity, still-births, miscarriages, and weight of largest baby born) was obtained. Height, weight, triceps skinfold thickness, and blood pressure (with subject in sitting position) were recorded. The subjects then remained at the survey centre and $2 \mathrm{~h}$ after the glucose load a further blood sample was taken.

All blood samples were centrifuged, separated, frozen, and stored. All biochemical measurements were performed on the SMAC 20 (Technicon Instruments Corporation) in the Biochemistry Department, Alfred Hospital, Melbourne. The SMAC uses a glucose oxidase method for measurement of plasma glucose levels.

Diagnostic Criteria for Diabetes. The criteria chosen for definition of diabetes were those used by Bennett et al. [5], i. e. patients with documented evidence of diabetes (known diabetics) and those who had a 2-h post-loading plasma glucose of $160 \mathrm{mg} / 100 \mathrm{ml}$ or more. Those who had a 2 -h post-loading plasma glucose level of $140-159 \mathrm{mg} / 100 \mathrm{ml}$ were classified as borderline diabetics.

Statistical Methods. Statistical analysis of the results was done using Student's " $t$ " test for unpaired variates. The criterion of significance was a $p$ value $<0.05$.

\section{Results}

\section{Overall Prevalence}

Of the 221 subjects aged 15 years and over who were tested, $54.3 \%$ had normal glucose tolerance, $11.3 \%$ were borderline diabetics, and $34.4 \%$ were diabetic (known and new) (Table 1).

\section{Age-Specific Prevalence}

The age-specific prevalence of diabetes is shown in Table 2. There were 23 subjects $(10.4 \%)$ who were previously known to be diabetic. In addition, 53 $(24 \%)$ new cases of diabetes were found. In the $15-19$ year age group, the prevalence was $5.7 \%$ rising to a peak of $68 \%$ in subjects $50-59$ years. Thus, $56 \%$ of the population aged 30 years and over have diabetes as defined above.

\section{Sex-Specific Prevalence}

The sex-specific prevalence is shown in Table 3. After the age of 40 years, prevalence rates were much higher in the females - apart from the 60 year and over group. A peak prevalence of $78.6 \%$ was seen in females aged 50-59 years, while that in the males was $54.6 \%$ in the same age group.

\section{Weight}

The means and standard error of mean of weights and heights of the normal subjects, borderline diabetics, and diabetics are shown in Table 4 . While there was a tendency for the weights of the new and known diabetics to be greater than those of the normal subjects, there was no significant statistical difference between any of the groups. However, if the male and female data are pooled, the difference in mean weight be-

Table 1. Classification of glucose tolerance of study population based on history of known diabetes or 2-h plasma glucose after $75 \mathrm{~g}$ oral glucose load

\begin{tabular}{lcc}
\hline Category & No. & $\begin{array}{l}\text { \% of } \\
\text { population } \\
\text { studied }\end{array}$ \\
\hline Normal & 120 & 54.3 \\
Borderline & 25 & 11.3 \\
Diabetic & 76 & 34.4 \\
\hline Total & 221 & 100.0 \\
\hline
\end{tabular}


Table 2. Specific prevalence of diabetes among the population aged 15 years and over (1975), i. e. 2 -h plasma glucose $160 \mathrm{mg} / 100 \mathrm{ml}$ or greater, or known diabetic. Borderline diabetics not included

\begin{tabular}{|c|c|c|c|c|c|c|}
\hline \multirow{2}{*}{$\begin{array}{l}\text { Age } \\
\text { group } \\
\text { (Yr) }\end{array}$} & \multirow[t]{2}{*}{$\begin{array}{l}\text { Number } \\
\text { examined }\end{array}$} & \multicolumn{2}{|c|}{$\begin{array}{l}\text { Known } \\
\text { diabetics }\end{array}$} & \multicolumn{2}{|c|}{$\begin{array}{l}\text { New } \\
\text { diabetics }\end{array}$} & \multirow{2}{*}{$\begin{array}{l}\text { Total with } \\
\text { diabetes } \\
\%\end{array}$} \\
\hline & & No. & $\%$ & No. & $\%$ & \\
\hline $15-19$ & 35 & 0 & 0 & 2 & 5.7 & 5.7 \\
\hline $20-29$ & 80 & 2 & 2.5 & 13 & 16.3 & 18.8 \\
\hline $30-39$ & 37 & 5 & 13.5 & 11 & 29.7 & 43.2 \\
\hline $40-49$ & 31 & 4 & 12.9 & 15 & 48.4 & 61.3 \\
\hline $50-59$ & 25 & 9 & 36.0 & 8 & 32.0 & 68.0 \\
\hline $60-$ & 13 & 3 & 23.0 & 4 & 30.8 & 53.8 \\
\hline Total & 221 & 23 & 10.4 & 53 & 24.0 & 34.4 \\
\hline
\end{tabular}

Table 3. Age and sex-specific prevalence of diabetes among the population aged 15 years and over. Borderline diabetics have not been included

\begin{tabular}{|c|c|c|c|c|c|c|}
\hline \multirow[t]{2}{*}{$\begin{array}{l}\text { Age } \\
\text { group } \\
\text { (Yr) }\end{array}$} & \multicolumn{2}{|c|}{$\begin{array}{l}\text { Number } \\
\text { examined }\end{array}$} & \multicolumn{2}{|c|}{$\begin{array}{l}\text { Number } \\
\text { with diabetes }\end{array}$} & \multicolumn{2}{|c|}{$\begin{array}{l}\text { Total } \\
\text { with diabetes } \\
\%\end{array}$} \\
\hline & M & $\mathrm{F}$ & M & $F$ & M & $\mathrm{F}$ \\
\hline $15-19$ & 18 & 17 & 1 & 1 & 5.6 & 5.9 \\
\hline $20-29$ & 34 & 46 & 6 & 9 & 17.6 & 19.5 \\
\hline $30-39$ & 21 & 16 & 9 & 7 & 42.8 & 43.8 \\
\hline $40-49$ & 16 & 15 & 8 & 11 & 50.1 & 73.8 \\
\hline $50-59$ & 11 & 14 & 6 & 11 & 54.6 & 78.6 \\
\hline $60-$ & 7 & 6 & 4 & 3 & 57.1 & 50.1 \\
\hline Total & 107 & 114 & 34 & 42 & 31.8 & 36.8 \\
\hline
\end{tabular}

tween normals and the newly diagnosed diabetics is significant $(p<0.05)$. It can be seen that the heights of all of the male and female groups were almost identical.

\section{Family History of Diabetes}

Of the 221 people tested, 66 did not know whether or not there was a family history of diabetes. Table 5 shows the responses of the other 155 subjects. While the number of normal and borderline diabetics with or without a positive family history was not different, $72 \%$ of the diabetics had a positive family history.

\section{Discussion}

The overall diabetes prevalence of $34.4 \%$ for individuals aged 15 years and over in this population greatly exceeds rates found in other Pacific and Western studies and matches that reported in the Pima Indians [5]. Borderline diabetes as defined in this
Table 4. Mean \pm standard error of mean of weight and height in males and females studied

\begin{tabular}{|c|c|c|c|c|}
\hline \multicolumn{2}{|c|}{ Classification } & \multirow{2}{*}{$\frac{\text { Number }^{\mathrm{a}}}{107}$} & \multirow{2}{*}{$\frac{\text { Weight }(\mathrm{kg})}{85.0 \pm 1.6}$} & \multirow{2}{*}{$\frac{\text { Height }(\mathrm{cm})}{165.1 \pm 0.6}$} \\
\hline All & males & & & \\
\hline & Normal & 59 & $83.5 \pm 2.1$ & $165.5 \pm 0.9$ \\
\hline & Borderline & 14 & $85.9 \pm 4.5$ & $165.1 \pm 1.0$ \\
\hline & Diabetic & 34 & $87.4 \pm 3.1$ & $164.4 \pm 0.9$ \\
\hline \multirow[t]{4}{*}{ All } & females & 112 & $79.5 \pm 1.8$ & $154.3 \pm 0.5$ \\
\hline & Normal & 61 & $77.8 \pm 2.4$ & $154.1 \pm 0.7$ \\
\hline & Borderline & 11 & $68.1 \pm 4.5$ & $152.6 \pm 1.6$ \\
\hline & Diabetic & 40 & $85.2 \pm 2.8$ & $155.1 \pm 0.9$ \\
\hline
\end{tabular}

a Two subjects were amputees and data on height and weight were not obtained

Table 5. Family history of diabetes in 155 people who were aware of the absence or presence of diabetes in their family

\begin{tabular}{llll}
\hline Classification & $\begin{array}{l}\text { Number } \\
\text { seen }\end{array}$ & $\begin{array}{l}\text { Negative } \\
\begin{array}{l}\text { F.H. of } \\
\text { diabetes } \\
\%\end{array}\end{array}$ & $\begin{array}{l}\text { Positive } \\
\text { F.H. of } \\
\text { diabetes } \\
\%\end{array}$ \\
\hline $\begin{array}{l}\text { Normal } \\
\text { Borderline }\end{array}$ & 79 & 47 & 53 \\
$\begin{array}{l}\text { Diabetic } \\
\text { (new and known) }\end{array}$ & 60 & 50 & 50 \\
\hline
\end{tabular}

study, would be accepted as diabetes by the FajansConn criteria [7]. Thus, $45.7 \%$ of the population have abnormal glucose tolerance using their criteria.

The prevalence of known diabetes was $10.4 \%$. The finding of two new diabetics for each known one is higher than seen in other studies $[5,8-10]$. The reason for this is not clear, but a possible explanation may be that the hyperglycaemia in this population (even if pronounced) is not usually accompanied by symptoms.

The age-specific prevalence data are similar to those reported by Bennett and co-workers [5] for the Pima Indians, with a progressive rise with increasing age and a fall again in subjects 60 years and over. There was no sex difference in prevalence in subjects less than 40 years. However, at ages 40 years and over, the rates for females were generally much higher. These findings are in accord with the experience of other workers $[5,10,11]$.

Of the diabetics in the present study, $72 \%$ had a family history of diabetes. In this population, there appears to be a strong hereditary influence with re- 
spect to the development of diabetes. Diabetes has been found to occur more frequently among blood relatives of diabetics than among relatives of nondiabetics by other workers $[9,12]$.

It is only in the last decade that diabetes has been recognized with any frequency in this population [13]. However, if a genetic tendency for the development of diabetes does exist, it is important to look at possible factors that would account for the apparent epidemic in this isolated population.

Other studies have clearly shown that prevalence rates for diabetes do increase with progressive urbanization [14-16]. The Westernization of the style of life on the island has led to an equivalent situation. Along with this, there has been a change in the traditional life-style to one of comparative inactivity.

There is a high prevalence of obesity in the community and the mean weight of the diabetics is significantly greater than that of the normal population [13]. In addition, the mean weights of the men and women were 11 and $19 \mathrm{~kg}$ higher, respectively, than those of a comparable Caucasian population [17].

A dietary survey of the island's population has shown a mean caloric intake of about 6100 calories/ day [18]. Of this, $48 \%$ was taken as carbohydrate, $33 \%$ as fat, and $15 \%$ as protein. Therefore, while the proportion of carbohydrate, fat and protein were not very different from those of an equivalent Western group, the caloric intake was at least twice that considered optimal by Western nutritional standards [19] and that recommended for developing Western Pacific countries [20].

The decrease in physical activity in relation to a high caloric intake must be seen as a possible major factor in the development of obesity in this population. Equally, it is possible, that the obesity per se has been a contributing factor to the increasing prevalence in a population having a strong hereditary susceptibility to diabetes. This would seem to be in accord with other studies which have been elegantly summarized by West [6]. Our dietary data support the concept that the most important dietary risk factor in increasing the risk of diabetes is the total caloric intake, irrespective of its source [21].

The high prevalence of glucose intolerance in this - and other similar groups - must necessarily raise the question as to whether the diabetes in these people is really the same disease as that observed in Caucasian populations. In view of the high incidence of diabetic complications in the population we have studied, the question seems to be answered in the affirmative. Of 52 of the known diabetics on the island, $45 \%$ had diabetic retinopathy and $33 \%$ had evidence of renal disease. Twelve of the diabetics have now died - all from diabetes-related causes [13].
Thus, as a group, these people suffer the same complications as Western diabetics.

The features of the diabetes are similar to those seen in other native populations and have been discussed by West [6]. The diabetes is maturity-onset in type and juvenile-onset diabetes is virtually unknown on the island. Despite quite marked hyperglycaemia, symptoms are often not apparent until plasma glucose levels reach $350-400 \mathrm{mg} / 100 \mathrm{ml}$. These features are similar to those of the diabetes described in other areas of the South Pacific [22].

The Pacific region is one area where the opportunity exists for comparative studies. Surveys in Melanesia $[23,24]$ indicate a comparative rarity of diabetes in contrast to the high prevalence rates in urbanized Polynesians and Micronesians [14, 16, 25, 26].

It is tempting to view the high prevalence of diabetes in this group in the light of Neel's "thrifty genotype" hypothesis [28] and to maintain that the clinical expression of diabetes has resulted from environmental factors impinging on a diäbetic genotype. It has been shown that, despite increasing Western influence, the incidence of diabetes in Eskimos and Melanesians has not increased significantly $[22,29]$. This is in marked contrast to the dramatic increase in the North American Indian and other native groups who have also been subjected to drastic changes in dietary habits and way of life in the past few decades. Thus, while environmental factors may play an important role, the importance of a possible diabetic genotype in these groups cannot be underestimated.

Acknowledgements. We acknowledge with gratitude the help of the Hon. Austin Bernicke, Minister for Health and Education, Republic of Nauru, who gave permission for the study to proceed, and without whose support it would not have been possible. We are indebted to Dr. D. Bennett and Mr. D. Harisson for help and advice in the computer analysis of data, and Miss R. Swan for help in preparing the manuscript. We are also grateful for the help of Miss Margaret Pearson, Senior Biochemist, Alfred Hospital. This work was supported by a grant from the National Health and Medical Research Council of Australia.

\section{References}

1. Wilkerson, H. L.C., Krall, L. P.: Diabetes in a New England town: A study of 3516 persons in Oxford, Massachusetts. J. A. M. A. 135, 209-216 (1947)

2. Scott, E.M., Griffiths, I. V.: Diabetes mellitus in Eskimos. Metabolism 6, 320-325 (1957)

3. Sagild, U., Littauer, J., Jepersen, C.S., Andersen, S.: Epidemiological studies in Greenland 1962 - 1964. 1. Diabetes mellitus in Eskimos. Acta Med. Scand. 179, 29-39 (1966) 
4. Mouratoff, G. J., Carroll, N. V., Scott, E. M.: Diabetes mellitus in Eskimos. J. A. M. A. 199, 107-112 (1967)

5. Bennett, P. H., Burch, T. A., Miller, M.: Diabetes mellitus in American (Pima) Indians. Lancet 1971 II, 125-128

6. West, K.M.: Diabetes in American Indians and other native populations of the New World. Diabetes 23, 841-855 (1974)

7. Fajans, S. S., Conn, J. W.: Prediabetes, subclinical diabetes, and latent clinical diabetes: interpretation, diagnosis, and treatment. In: On the nature and treatment of diabetes (eds. B.S. Liebel, G. A. Wrenshall), pp. 641-656. Amsterdam: Excerpta Medica Foundation 1965

8. Stein, J.H., West, K.M., Robey, J.M., Tirador, D.F., McDonald, G. W.: The high prevalence of abnormal glucose tolerance in Cherokee Indians of North Carolina. Arch. Intern. Med. 116, 842-846 (1965)

9. Welborn, T. A., Curnow, D. H., Wearne, J. T., Cullen, K. J., McCall, M. G., Stenhouse, N. S.: Diabetes detected by bloodsugar measurement after a glucose load: report from the Busselton survey, 1966. Med. J. Aust. 2, 778-783 (1968)

10. Marine, N., Vinik, A. I., Edelstein, O., Jackson, W. P. U.: Diabetes, hyperglycaemia and glycosuria among Indians, Malays and Africans (Bantu) in Cape Town, South Africa. Diabetes 18, 840-857 (1969)

11. McDonald, G. W.: Epidemiology of diabetes. In: Diabetes mellitus: theory and practice (eds. M. Ellenberg, H. Rifkin), pp. 528-593, New York: McGraw-Hill 1970

12. Pincus, G., White, P.: On the inheritance of diabetes mellitus. I. An analysis of 657 family histories. Am. J. Med. Sci. 186, 1-14 (1933)

13. Zimmet, P., Taft, P.: The high prevalence of diabetes mellitus on a Central Pacific island. In: Epidemiology of diabetes (eds. M. Miller, P. H. Bennett), New York: Academic Press (in press)

14. Prior, I. A. M., Davidson, F.: The epidemiology of diabetes in Polynesians and Europeans in New Zealand and the Pacific. N. Z. Med. J. 65, 375-383 (1966)

15. Poon-King, T., Henry, M. V., Rampersad, F.: Prevalence and natural history of diabetes in Trinidad. Lancet $1968 \mathrm{I}$, $155-160$

16. Reed, D., Labarthe, D., Stallones, R., Brody, J.: Epidemiological studies of serum glucose levels among Micronesians. Diabetes 22, 129-136 (1973)

17. Welborn, T. A., Murphy, B.P., Stewart, A. J., Fullerton, R., Finch, P. S.: Prevalence of cardiovascular risk factors including fasting triglyceride levels in the Cunderdin Health Survey of 1971. Med. J. Aust. 2, 199 (1976)

18. Zimmet, P., Taft, P., Guinea, A., Bennett, D., Ringrose, H., Thoma, K.: Epidemiological factors relating to the high diabetes prevalence on a Pacific island. Diabetologia 12 (Abstr.), 421 (1976)

19. National Health and Medical Research Council.: Dietary allowance for use in Australia. Canberra: Australian Government Publishing Services 1971

20. World Health Organization.: The health aspects of food and nutrition. Manila: Western Pacific Regional Office 1969

21. West, K. M.: Prevention and therapy of diabetes mellitus. Nutr. Rev. 33, 193-198 (1975)

22. Zimmet, P.: Clinical and epidemiological aspects of diabetes in the South Pacific region. In: Report of Seventh Conference on Health Services pp. 15-88. Noumea: South Pacific Commission (1976)

23. Hingston, R. G., Price, A. V. G.: Diabetic surveys in Papua. Papua New Guinea Med. J. 7, 33-35 (1964)

24. Cassidy, J. T.: Diabetes in Fiji. N. Z. Med. J. 66, 167-172 (1967)

25. Sloan, N. R.: Ethnic distribution of diabetes mellitus in Hawaii. J. A. M. A. 183, 419-424 (1963)

26. Yen, S.S.C.: Abnormal carbohydrate metabolism and pregnancy. Am. J. Obstet. Gynecol. 90, 468-473 (1964)

27. Wise, P.H., Edwards, F.M., Thomas, D.W., Elliot, R.B., Hatcher, L., Craig, R.: Hyperglycaemia in the urbanized aboriginal. The Davenport survey. Med. J. Aust. 2, 1001-1006 (1970)

28. Neel, J. V.: Diabetes mellitus: a thrifty genotype rendered detrimental by "progress"? Am. J. Hum. Genet. 14, 353-362 (1962)

29. Schaefer, O.: Glucose tolerance testing in Canadian Eskimos. A preliminary report and a hypothesis. Can. Med. Assoc. J. 99, $252-262(1968)$

Received: August 6, 1976, and in revised form: December 8, 1976

Dr. P. Zimmet, Director

Dept. of Metabolic Medicine \& Epidemiology

Southern Memorial Hospital

260 Kooyong Road

Caulfield, Victoria 3162, Australia 